\title{
CORRECTION
}

\section{Correction to: Recognizing Gynecological Cancer in Primary Care: Risk Factors, Red Flags, and Referrals}

\author{
Garth Funston $\cdot$ Helena O'Flynn · Neil A. J. Ryan · Willie Hamilton • \\ Emma J. Crosbie
}

Published online: April 4, 2018

(c) The Author(s) 2018

Correction to: Adv Ther https://doi.org/10.1007/ s12325-018-0683-3

The article "Recognizing Gynecological Cancer in Primary Care: Risk Factors, Red Flags, and Referrals", written by Garth Funston, Helena O'Flynn, Neil A. J. Ryan, Willie Hamilton, Emma J. Crosbie was originally published electronically on the publisher's internet portal (currently Springer-Link) on March 07, 2018 without open access.

With the author(s)' decision to opt for Open Choice the copyright of the article changed on March 25, 2018 The Author(s) [2018] and the

The original article can be found online at https://doi. org/10.1007/s12325-018-0683-3.

G. Funston $(\bowtie) \cdot$ H. O'Flynn

Centre for Primary Care, University of Manchester, Manchester, UK

e-mail: gf272@doctors.org.uk

N. A. J. Ryan - E. J. Crosbie

Gynaecological Oncology Group, University of

Manchester, Manchester, UK

W. Hamilton

Exeter Medical School, University of Exeter, Exeter, UK article is forthwith distributed under the terms of the Creative Commons Attribution [continuing for CC BY NC].4.0 International License (http://creativecommons.org/licenses/by/4.0/), which permits use, duplication, adaptation, distribution and reproduction in any medium or format, as long as you give appropriate credit to the original author(s) and the source, provide a link to the Creative Commons license, and indicate if changes were made.

The original article has been corrected.

Open Access. This article is distributed under the terms of the Creative Commons Attribution-NonCommercial 4.0 International License (http://creativecommons.org/licenses/ by-nc/4.0/), which permits any noncommercial use, distribution, and reproduction in any medium, provided you give appropriate credit to the original author(s) and the source, provide a link to the Creative Commons license, and indicate if changes were made. 